\title{
The Two Postwar Eras and the Conditions for Stability in Twentieth-Century Western Europe
}

\section{Citation}

Maier, Charles S. 1981. The two postwar eras and the conditions for stability in twentieth-century Western Europe. American Historical Review 86(2): 327-352.

\section{Published Version}

doi: $10.2307 / 1857441$

\section{Permanent link}

http://nrs.harvard.edu/urn-3:HUL.InstRepos:4727674

\section{Terms of Use}

This article was downloaded from Harvard University's DASH repository, and is made available under the terms and conditions applicable to Other Posted Material, as set forth at http:// nrs.harvard.edu/urn-3:HUL.InstRepos:dash.current.terms-of-use\#LAA

\section{Share Your Story}

The Harvard community has made this article openly available.

Please share how this access benefits you. Submit a story.

Accessibility 


\title{
AHR Forum
}

\section{The Two Postwar Eras and the Conditions for Stability in Twentieth-Century Western Europe}

\author{
CHARLES S. MAIER
}

BROADCASTING over the BBC in November 1945, A. J. P. Taylor assured his listeners, "Nobody in Europe believes in the American way of life-that is, in private enterprise; or rather those who believe in it are a defeated party and a party which seems to have no more future than the Jacobites in England after 1688." "Taylor proved to be wrong, or at least premature, about the end of private enterprise. The question here is why, at least in Western Europe, there was less transformation than he envisaged. Posed in broader terms, how did Western Europe achieve political and social stability by the mid-twentieth century after two great, destructive wars and the intervening upheaval.

Historians often treat stability as a passive coming to rest or a societal inertia that requires no explanation. In fact, stabilization is as challenging a historical problem as revolution. It can emerge dramatically. As one historian who has focused on the process wrote, "Political stability, when it comes, often happens to a society quite quickly, as suddenly as water becomes ice."' Stabilization, moreover, does not preclude significant social and political change but often requires it. Certainly the two world wars broadened democracy in Britain and stimulated economic transformation in France. World War II finally removed the contradictions between modernity and reaction in Germany, thereby facilitating a meritocratic pluralism. Yet, despite the transformations, earlier liberal and elitist arrangements that governed the distribution of wealth and power either persisted or were resumed after authoritarian intervals. And at least until

This article was originally drafted during tenure of a fellowship from the National Endowment for the Humanities to pursue research on the United States and European reconstruction after World War II. Previous versions benefited from conversation with Duke University colleagues as well as from discussion at seminars at the University of Wisconsin in Madison, Princeton University, Harvard University, and the European Studies Center at the University of Chicago, and at Werner Conze's seminar for social and economic history at Heidelberg. A semi-final draft was presented as a paper at the Ninety-Third Annual Meeting of the American Historical Association, held in San Francisco, December 1978. I am grateful to Leonard Krieger, Richard Kuisel, and Carl Schorske for their comments at that session. The present version is especially indebted to the suggestions of Professor Kuisel, the subsequent critiques by the anonymous referees for the American Historical Review, and the comments of Patrick Fridenson of the University of Paris-X (Nanterre).

${ }^{1}$ Taylor, "The European Revolution," Listener (London), November 22, 1945, p. 576.

2 J. H. Plumb, The Origins of Political Stability: England, 1675-1725 (Boston, 1967), xvii. 
the end of the 1960s the societies of Western Europe seemed more cohesive, humdrum, and routine than either those who feared change or those who longed for it would have predicted.

The key to this stability lies in both postwar eras, the period after World War I as well as that after World War II. Although the years after the first war did not bring enduring stabilization, neither did they produce the radical economic and social change that Left and Right had expected. Outside Russia the first war opened the way only to limited upheaval, conservative reconstruction, or, in some cases, counterrevolution. With the end of the second war, as Taylor's prognosis suggested, many observers again anticipated a major social transformation. This time the postwar years brought not only an ebbing of radicalism but at least a generation of political and economic stability as well. Yet that midcentury stability rested upon the cumulative achievements of both postwar eras. Together the postwar intervals comprised two chapters in a single half-century effort by reform-minded and conservative elites to exploit postwar circumstances for a successful restructuring of the hierarchies they dominated.

GIVEN THE OBJECTIVE OF HISTORICAL COMPARISON, the two periods are usefully envisaged as complementary and parallel alike. Complementary (as is stressed below) in that each made its own distinct but partial contribution to the process of channeling change. Parallel in that key political and economic developments tended to recapitulate themselves. The recurring elements after both wars demonstrate that, although many problems were different, the same underlying political cleavages, enduring class and industrial conflicts, and continuing economic dilemmas remained. As in earlier postwar transitions, each period witnessed a swing from radical challenge to political consolidation. Such a trajectory had marked Europe in the aftermath of the wars of the French Revolution and Napoleon, Russia following the Crimean War, Italy, Prussia, and Austria after the wars of unification, the United States after its Civil War, and France again in the wake of 1870, Spain after 1898, and Russia after 1905. The periods after the two world wars likewise reveal certain parallels.

Consider, first, the comparable political developments. Just as radical or reformist forces of the Left seemed ready to impose extensive changes and then lost their impetus between 1918 and 1921, so the Resistance-born coalitions of Communists, Socialists, Catholics, and liberal democrats initiated reforms but collapsed by 1947-48. In both cases this disarray followed early polarization within the working-class parties and unions. From the viewpoint of the moderates, Soviet-oriented leaders grew ruthlessly opportunistic and sectarian; reverse the perspective and Social Democrats appear preoccupied with Bolshevism or communism. After both wars, too, the respective Catholic parties-the German Zentrum and the Italian Popolari after 1918, the diverse Christian Democrats after 1945-also retreated from their earlier commitments to boldly proclaimed economic reforms. Catholic trade-union leaders and left intellectuals lost out to spokesmen for middle-class stability, the Church hierarchy, or "social-market liberalism." 
A careful distinction is necessary here. After 1945, plans to supersede capitalism yielded to efforts to reinvigorate economic liberalism. Yet liberal party organizations continued the long-term decline that had originated even before World War I. This attrition hurt both right- and left-wing variants of liberalism, although the Right could fall back upon the economic interest groups it dominated and the Left still controlled influential journalistic outposts. Electoral support, however, was a different story. Voting results were prevailingly disappointing. In 1946 Italian laissez-faire Liberals and the reformist Actionists together polled no more than 8 percent of the electorate. The French non-Marxist, nonCatholic Left had brilliant writers but few voters. Belgian Liberal deputies were returned at roughly half of their prewar strength with about 9 percent of the popular poll, and the revived Liberal Democratic party in West Germany (today's Free Democrats), with its 9.5 percent in Landtag elections and 12 percent of the first Bundestag, remained comparable to voting results of the combined Democratic (Staatspartei) and People's parties in the late Weimar Republic. $^{3}$

Just as striking as the draining of energy on the Left in the respective postwar years was the recapitulation of key industrial and monetary developments. Certainly the economy of the era after 1948 became far more robust than the ephemeral prosperity of the late 1920s. Nonetheless, some of the same dilemmas and solutions marked both recoveries. By the mid-1920s Americans were finally helping ease Europe's postwar balance-of-payments difficulties by the enthusiastic purchase of European bonds. At the same time, leading bankers on both sides of the Atlantic pressed for currency stabilization and monetary convertibility on the basis of the gold-exchange standard: the Reichsmark was anchored in late 1924, sterling in April 1925, the lira in 1927, and the French franc (legally re-established exclusively on a gold base) in 1928. The laboriously negotiated tariff compromises and trade treaties of the latter 1920s along with such interindustry agreements as the Entente Internationale de l'Acier advanced the integration of the major Continental steel and chemical producers. Agreements between industries across frontiers encouraged mergers and concentration within the component national economies. In a similar sequence after World War II, the European Recovery Program of 1948-51 and subsequent Mutual Security assistance provided American credits to compensate for Europe's massive dollar deficit. The European Payments Union, the product of negotiations extending from 1948 to 1951, worked toward renewed currency convertibility. The Coal-Steel Community of the early 1950s reinforced the capitalist revival of the second postwar period. ${ }^{4}$

\footnotetext{
${ }^{3}$ For a useful tabulation of voting results, see Derek W. Urwin, ed., Elections in Western Nations, 1945-1968, University of Strathclyde, Survey Research Center, Occasional Papers, nos. 4-5 (Glasgow, n.d.).

${ }^{4}$ For the negotiations of the 1920s, see Charles S. Maier, Recasting Bourgeois Europe: Stabilization in France, Germany, and Italy in the Decade after World War I (Princeton, 1975), 516-45; and Jacques Bariéty, "Das Zustandekommen der Internationalen Rohstahlgemeinschaft (1926) als Alternative zum misslungenen 'Schwerindustriellen Projekt' des Versailler Vertrages," in Hans Mommsen et al., eds., Industrielles System und politische Entwicklung in der Weimarer Republik (Düsseldorf, 1974), 552-68. For the negotiations between coal and steel producers after World War II, the material in the steel trusteeship papers at the Koblenz Bundesarchiv [hereafter, BA], B 109/97, is revealing; these papers are complemented by the memoranda of meetings included in
} 
Obviously, there were crucial differences between the two postwar eras; to discern parallels is not to claim identities. After the First World War, to cite just a first salient difference, the political Right emerged more militant than before 1914. Fascism drew upon a striking force of veterans inured to violence and contemptuous of civilian virtues. After the Second World War, fascism was discredited and even traditional conservative nationalism rejected. The psychological impact of the fighting did not create nuclei of Arditi, Free Corps recruits, or others addicted to paramilitary violence. For most soldiers the second war impelled instead a search for private fulfillment: "the happy obscurity of a humdrum job and a little wife and a household of kids," according to Bill Mauldin, or, a front away, the return to "the mountains of the Caucasus, the exciting blue smoke of the foothills ..., the sweet faces of loved ones." 5 What analogue existed after 1945 to the trinceismo, the glorification of the trenches of World War I, was the partisans' mountain ordeal: a trial that Resistance spokesmen claimed was moral justification for a new elite, although without any encouragement for a continuing cult of violence. Indeed, the distinction in 1914-18 between front soldiers mired down in brutalizing combat and male civilians at home who sometimes enjoyed cushy, protective berths - the so-called embusqués or imboscati-dissolved in 1939-45 with the rapid movement of troops, the air attacks on civilian targets, and the hardships of occupation. Almost 50 percent of Europe's dead in the second war were civilians, compared to about 5 percent in the first. ${ }^{6}$ These factors all contributed to limiting the potential of any veterans-based right radicalism. Except for the recurring but small German nationalist splinters, achieving at best 8 to 10 percent electoral support at the Land level (and about 2 percent in national polls), the search for right-wing movements after 1945 yields only ambivalent possibilities: the Gaullism of 1947 and the Uomo Qualunque of southern Italy, a sort of pre-Poujadism that rejected the moralistic claims of the Resistance Left. This failure of the neofascist Right to emerge in greater strength was a major surprise of postwar European politics. ${ }^{7}$

the archives of the Compagnie de Pont-à-Mousson at La Châtre [hereafter, PAM], boxes 70669, 70671, 70690-91, 77042. Also see William Diebold, Jr., The Schuman Plan: A Study in Economic Cooperation, 1950-1959 (New York, 1959). For monetary negotiations, see Stephen V. O. Clarke, Central Bank Cooperation, 1924-1931 (New York, 1967); Sir Henry Clay, Lord Norman (London, 1957); L. V. Chandler, Benjamin Strong, Central Banker (Washington, 1958); W. A. Brown, Jr., England and the New Gold Standard, 1919-1926 (New Haven, 1929), and The International Gold Standard Reinterpreted, 1914-1934, 2 vols. (New York, 1940); Donald E. Moggridge, British Monetary Policy, 1924-1931: The Norman Conquest of \$4.86 (Cambridge, 1972); and Gerd Hardach, Weltmarktorientienung und relative Stagnation: Währungspolitik in Deutschland, 1924-1931, Schriften zur Wirtschafts- und Sozialgeschichte, vol. 27 (Berlin, 1976). For post-1945 negotiations, see William Diebold, Jr., Trade and Payments in Western Europe (New York, 1952); J. Kummell, De Ontwikkeling van het Internationale Betalingsverkeer (Leiden, 1950); Robert Triffin, Europe and the Money Muddle (New Haven, 1957); and Raymond F. Mikesell, Foreign Exchange in the Postwar World (New York, 1954).

5 As quoted in John Morton Blum, V Was for Victory: Politics and American Culture during World War II (New York, 1976), 70, 73. For the attitudes and political organization of veterans, only a minority of whom became radically antidemocratic, see James M. Diehl, Paramilitary Politics in Weimar Germany (Bloomington, Ind., 1977); Volker R. Berghahn, Der Stahlhelm, Bund der Frontsoldaten, 1918-1935 (Düsseldorf, 1966); Robert G. L. Waite, Vanguard of Nazism: The Free Corps Movement in Postwar Germany, 1918-1923 (Cambridge, Mass., 1952); Giorgio Sabatucci, I combattenti nel primodopoguerra (Bari, 1974); and Antoine Prost, Les Anciens combattants et la société française, 1914-1939, 3 vols. (Paris, 1977), esp. volume 3: Idéologies et mentalités.

${ }^{6}$ Gordon Wright, The Ordeal of Total War, 1939-1945 (New York, 1968), 264.

${ }^{7}$ For the Gaullism of 1947, see Jean Touchard, Le Gaullisme, 1940-1969 (Paris, 1978), 98-133. On Uomo Qualunque, see Sandro Setta, L'Uomo Qualunque, 1944/48 (Bari, 1975). And, for post-1945 Germany, see Kurt P. Tauber, Beyond Eagle and Swastika: German Nationalism since 1945, 2 vols. (Middletown, Conn., 1967). 
Only in retrospect is it discernible that even under the collaborationist regimes conservative elements had to rethink the economic role of the state and the future relationship of capital and labor. To cite just the French situation (although analogues existed in the Netherlands and the Salò Republic), awareness that the Vichy regime was doomed and mass upheaval likely prompted the industrialists summoned by the Conseil Supérieur de l'Économie Industrielle et Commerciale to search for a "factory community" that would provide a "balanced solution" between "yesterday's capitalism" and "collectivism." Such explorations, however, could build upon more than fear of postwar revolution. They carried forward some of the heterodox notions of economic planning that dissenting socialists and conservative intellectuals alike had outlined in the 1930s. ${ }^{8}$

A major condition for a more flexible Right was the fact that the Left too debarked differently after the second war. Between 1918 and 1921 the European working classes had first surged into spontaneous demonstrations, had then waged long, disciplined mass strikes, and had finally retrenched in frustration and divided. Much of their insurrection followed from the intensified labor discipline the war imposed as well as progressive ideological alienation from its national objectives. The second war imposed some of the same ordeals within the factory, but the German occupation made the factory a less central source of oppression. The heirs of the working-class leadership that had come to oppose the first war by 1917 urged active resistance to the Germans after June 1941, so that the second war was less an alien upper-class cause than an arduous wait for liberation. Its conclusion thus brought a different tempo of working-class cooperation and protest. Western Communists played down any radical economic transformation that outran the broad Resistance consensus on purges and the nationalization of key industries or those tainted by their owners' collaboration. Instead Communist leaders stressed anti-Nazi unity (until the final defeat of Germany) and continuing production, even at the cost of harsh industrial discipline. "The bonus per ton is evil," wrote one CGT leader in March 1945 about detested pay differentials, "but coal is necessary." Maurice Thorez insisted to coal miners at Waziers in July 1945 that production itself was a demonstration of solidarity, militancy, and working-class power. "Only by working, only by working hard will we be able to overcome this situation [of hardship]," the secretary of the Milan Chamber of Labor told the factory council of Magneti Mirelli in early 1946. "We all seek socialism. But do you believe that we can

\footnotetext{
${ }^{8}$ Conseil Supérieur de l'Économie Industrielle et Commerciale, Commission Nr. 4, Procès-Verbal de la séance du 5 novembre 1943, PAM, box 70411; and Report to the Minister, July 17, 1944, ibid. Also $\rightarrow$ Richard Kuisel, "Vichy et les origines de la planification économique (1940-1946)," Le Mouvement Social, 98 (1977): 77 $\rightarrow$ Jacques Amoyal, "Les Origines socialistes et syndicalistes de la planification en France," ibid., 87 (1974): 137-69; and, on the labor issue, Jacques Julliard, "La Charte du Travail," in Jeanine Bourdin, ed., Le Gouvernement de Vichy, 1940-1942: Colloque de la Fondation Nationale des Sciences Politiques (Paris, 1972), 157-210.

${ }^{9}$ L. Delfosse, in La Tribune des Mineurs, March 18, 1945, as quoted in Jean Bouvier, "Région et Nation: Inflation, reformes de structures, nationalisation des houillères, et crise sociale," Actes du Colloque de l'Université de Lille III, 2-3 novembre 1974: La Libération du Nord et du Pas-de-Calais, 1944-1947 [hereafter, Colloque de Lille], in Revue du Nord, 57 (1975): 609. For Communist policies, see J.-P. Hirsch, “'La Seule voie possible': Remarques sur les communistes du Nord et .du Pas-de-Calais de la Libération aux grèves de novembre 1947," ibid., 56378, which contains an extensive discussion of Thorez's celebrated Waziers appeal, July 21, 1945.
} 
socialize poverty?" Communists, warned Jacques Duclos, as he condemned the 1946 Socialist-supported strikes of French civil servants, had to demonstrate "that democracy is a regime of order, a regime of tranquility and of work."

The open question in France, Belgium, and Italy (to the extent that the Anglo-American occupation would have permitted) was whether an angry and long-repressed working class would explode in a spontaneous radicalism with plant seizures, local "socialization," and summary trials. Communist pressure for carrying through purge procedures probably helped contain grass-roots grievances. In fact, whether in France, Italy, Belgium, Holland, or Bavaria (under American auspices), the purges became more and more restricted. Categories of guilt seemed to blur hopelessly, and moderates came to grasp that trying business leaders for cooperation with the Germans could have radical consequences, or, in the words of one Esprit intellectual who advocated it, "The purge of the economic sector entails overturning all property relations." " Purges were thus wound down short of any major upheaval, and the emphasis upon sifting individuals probably diverted effort from institutional transformationalthough originally the Left had envisaged épuration as a mode of collective change.

Perhaps, however, the major force for preventing ideological polarization after World War II was neither the chastened Right nor the tempered Left but the new Christian Democratic parties of the center. For the crucial three years after 1944, left Catholicism with its declared hostility to liberal capitalism seemed ascendant. The appearance was deceptive in the long run, but it served well to contain otherwise radical currents in the flux of the immediate postwar period. Konrad Adenauer could swallow and survive the radical-sounding Ahlen Program of the Westphalian Christian Democrats in 1947, understanding that it kept the CDU from appearing reactionary; Alcide De Gasperi ultimately profited from the mass base organized by Catholic labor leader Achille Grandi; and the French MRP accepted nationalization but, except for collaborators, insisted upon compensation. ${ }^{12}$ In Italy and Belgium the prolonged controversy

\footnotetext{
${ }^{10}$ Milanese secretary of the Chamber of Labor, as quoted in Febo Guizzi, "La Fabbrica italiana Magneti Marelli," in Luigi Ganapini et al., La ricostruzione nella grande industria: Strategia padronale e organismi di fabbrica nel Triangolo, 1945-1948 (Bari, 1978), 280; and Duclos, as quoted in Alain Bergonieux, Force Ouvrière (Paris, 1975), 55.

${ }^{11}$ G. Zérapha, "Le Problème politique français," Esprit, December 1944, as quoted in Michel Winock, Histoire politique de la revue "Esprit" (Paris, 1975), 260. On the purges, see Peter Novick, The Resistance versus Vichy (New York, 1968); Robert Aron, Histoire de l'épuration, 3 vols. (Paris, 1967-75); D. Laurent et al., "Sur l'épuration dans le Nord et le Pas-de-Calais," Colloque de Lille, in Revue du Nord, 57 (1975): 365-80, 623-36; Lutz Niethammer, Entnazifizierung in Bayern: Säuberung und Rehabilitierung unter amerikanischer Besatzung (Frankfurt a/M, 1972); and Marcello Flores, "L'Epurazione," in Instituto Nazionale per la Storica del Movimento di Liberazione in Italia, L'Italia dalla liberazione alla repubblica; del convegno internazionale . . 26-28 marzo 1976 (Milan, n.d.), 413-67. Also see Guizzi, "La Fabbrica italiana Magneti Marelli," 245-72; and Valerio Castronovo, Giovanni Agnelli (Turin, 1971), 671-88. Also see the reports from U.S. diplomats on the slowing of the Belgian and Dutch purges, National Archives, Washington, Record Group 59 [hereafter, NA-RG 59], including the report by Charles Sawyer, May 29, 1945, NA-RG 59,855.00/5-2945; by Theodore Achilles, June 11, 1946, ibid., 855.00/6-1146; and by J. Webb Benton from the Hague, August 15, 1946, ibid., 856.00/8-1546.

${ }^{12}$ For Adenauer's views, see Sozialausschuss der CDU, February 21-22, 1947, in Friedrich-Ebert-Stiftung, Bonn, Hensler Nachlass, 16. Also see Gerold Ambrosius, Die Durchsetzung der sozialen Marktwirtschaft in Westdeutschland, 1945-1949 (Stuttgart, 1977); and Konrad-Adenauer-Stiftung, Konrad Adenauer und die CDU der britischen Besatzungszone, 1946-1949 (Bonn, 1975), 46-47, 288-89. On Grandi, see Benedetto de Cesaris, "Cattolici,
} 
over the fate of the discredited monarchs helped the Catholic parties accommodate both Left and Right. As the American embassy reported from Brussels, the Christian Social party, by defending the rights of Leopold III, could retain the allegiance of Belgian conservatives, even while letting its trade unionists champion social reform, and could thus provide "all things to all men who believe in the Roman Catholic religion." 13 This capacity naturally undermined the radical élan of Christian democracy but did allow the movement to serve as an integrating force for moderation.

Domestic party developments obviously took place under the shadow of the great powers. The overwhelming difference between 1918 and 1945 was the continuing intervention of the United States and the Soviet Union in their respective spheres of influence. But in Western Europe, American aid, with its attendant pressure, was only one of many factors abetting liberal reconstitution. The discrediting of the European Right, the fear of Communist motives and the Soviet Union that replaced Popular Front effusions, and the desire on the part of both Christian Democrats and Social Democrats to establish moderate welfare states were powerful impulses on their own. They alone sufficed to make 1945 different from 1918.

DIFFERENT, BUT NOT SEPARATE. Both postwar periods, as noted, formed part of a continuing effort at stabilization, a search that was sufficiently active and persistent (and rewarded finally with sufficient success) to comprise a major theme of twentieth-century Western European history. Stabilization, however, for whom? And of what? Stabilization meant not so much preserving liberal procedures as re-establishing the overlapping hierarchies of power, wealth, and status that can be loosely termed "capitalist." In an age of mass suffrage, these challenged hierarchies had to be defended less in terms of custom than results-that is, their performance for society as a whole. Increasingly, performance included the maintenance of economic welfare. The Depression led voters to shatter the Western political coalitions of the 1920s even when it did not destroy democratic regimes. Distress forced governments in the 1930s to become employers of last resort; by the 1950s they were called upon to assure continuing economic growth as well as high employment at a given level of national income. Stabilization thus entailed a dual task. It meant re-establishing the contested legitimacy of European social and economic elites-buttressing the hierarchies that even in an age of mass voting still presupposed that only small minorities could share the prerogative of directing human labor. Justifying inequality, in turn, required satisfying criteria of economic performance: figuratively and literally delivering the goods. Although they had to broaden their recruitment and recognize new spokesmen for organized labor, by and large the elites superin-

eredità 'popolari,' e nuovo stato," in Problemi del movimento sindacale in Italia, 1943-1973: Annali della Fondazione Giangiacomo Feltrinelli, 16 (1976): 229-39. For the MRP stance, see the discussions of Bidault and Menthon with Communist and Socialist leaders, January 23, 1945, Colloque de Lille, in Revue du Nord, 57 (1975): 596-97.

${ }^{13}$ Jefferson Patterson to the Department of State, August 20, 1945, NA-RG 59, 855.00/8-2045. 
tending Western society met these related conditions for stability-those of legitimation and those of production. But they did not meet both conditions at once.

Instead, Europe's elites resolved their difficulties seriatim, such that each effort of postwar stabilization overcame one of the two challenges. With the 1920s came not a total, but a nevertheless impressive, response to the ideological attack upon the legitimacy of capitalist hierarchies as hierarchies. That is, the leaders of the 1920s rallied with persuasive justifications of capitalist entrepreneurship. They ended up rejustifying not so much ownership per se as a hierarchy of managerial power that preserved the essentials of control. Nonetheless, the 1920s did not solve the economic dilemma of ensuring continuous production and high employment. That task was left to the second postwar period. Only by the 1950 s were the afflictions that undermined capitalist stability effectively overcome as a whole. The cumulative achievement required the institutional flux that was left in the wake of not one but two wartime upheavals.

In what sense can it be maintained, however, that developments of the 1920s served durably to reinforce the legitimacy of European capitalism? In light of mass unemployment, the taint of wartime collaboration, and the wave of socialist aspirations incorporated in the Resistance, did not capitalism seem as shaken, vulnerable, and problematic after World War II as ever before-hence A. J. P. Taylor's verdict? In fact, however, the Left's programs after World War II did not often go so far as the challenges of $1918-21 .{ }^{14}$ This does not mean that the Left was universally stronger earlier. Although in Germany and Italy social revolutionary outcomes had been more feasible after the First than the Second World War (if only because no occupying forces were present), had it chosen to exploit its power, the French Left possessed a more commanding position in late 1944 than it had controlled in 1918. In Britain the protests of 1918-19 that looked toward a syndicalist socialism were succeeded in 1945 by the more solid, if more moderate, triumph of the Labour party. In short, the relative strength of the Left in the respective postwar periods depended to a great extent upon the particular national situation. The programs of the Left, however, often remained a less clearcut challenge after 1944 than they were after 1918. They aspired less to overturn bureaucratic and economic control than to attain public ownership of key industries. By 1945, however, ownership was a less crucial issue than earlier for many sectors that the Left targeted for nationalization. The earlier socialist challenge that followed in the wake of the Bolshevik Revolution with its innovation of soviets was probably more fundamental. What the participants in the massive strikes and insurrections of 1918-21, the militants at party and union congresses, and the remarkable socialist theorists of the early 1920 s urged in aggregate was not merely the centralization of important industries in

\footnotetext{
${ }^{14}$ On this point, see some of the recent surveys of this period, including Francis Carsten, Revolution in Central Europe, 1918-1919 (London, 1972); Charles L. Bertrand, ed., Revolutionary Situations in Europe, 1917-1922: Germany, Italy, Austria-Hungary, Proceedings of the Second International Colloquium of the Interuniversity Center for European Studies (Montreal, 1977); and Rivoluzione e reazione in Europa, 1917/1924: Convegno storico internazionale, Perugia, 1978 (Rome, 1978).
} 
the hands of the state; this demand came from moderate Social Democrats. Instead, they criticized managerial control of the workplace and of production regardless of ownership; and, by extension, they challenged the chains of command of the Western economies from top to bottom.

These movements failed in the West for many reasons. They were rooted in the shop steward organizations of the Clydeside, the factory grievance committees established during the war to smooth labor relations, which in turn helped generate the consigli di fabbrica of Turin and the Räte in Germany and Austria. Some spokesmen for these councils envisioned a syndical reorganization of the economy and politics. But often their militancy derived from the more conservative impulses of defending the work skills and artisanal independence still conserved under factory roofs against degrading standardization of tasks and wartime "dilution" (the hiring of unskilled replacements, sometimes women).${ }^{15}$ Moreover, the councils comprised a strong movement only in a few industrial regions, and their revolts exploded out of phase with each other. The movement, moreover, appears to have evoked the least resonance in France, which would still have had to be the keystone of any general West European transformation. In France, reformist socialists as well as industrial leaders restricted the mandate of factory delegates, while after the armistice radicals spilled into street demonstrations that were militant but diffuse and finally settled on a program for nationalization of the railroads. ${ }^{16}$ Likewise in Britain, Labour militants came to focus upon takeover of the coal industry. In Germany, the councils emerged during revolution but often just to take charge of factories, regiments, or towns in which central authority crumbled. When German council champions took up explicitly socialist goals, they incurred drastic repression, as in Munich in April 1919 or in the Ruhr after the Kapp Putsch. ${ }^{17}$

Trade-union leaders, moreover, remained cool toward alternative modes of representation, fearing that the new councils would undercut their long, patient

\footnotetext{
${ }^{15}$ On the resistance of skilled workers, see James Hilton, The First Shop Stewards' Movement (London, 1973); $\rightarrow$ Bertrand Abhervé, "Les Origines de la grève des métallurgistes parisiens, juin 1919," Le Mouvement Social, 93 (1975): 75-85; $: \rightarrow$ David Montgomery, "The 'New Unionism' and the Transformation of Workers' Consciousness in America, 1909-1922," Journal of Social History, 7 (1974): 509-29. Also see Carmen J. Sirianni, "Workers' Control in the Era of World War I: A Comparative Analysis of the European Experience," Theory and Society, 9 (1980): 29-88; and Martin Clark, Antonio Gramsci and the Revolution that Failed (New Haven, 1977).

${ }^{16}$ Abhervé, "Les Origines de la grève des métallurgistes parisie $\rightarrow$ Nicholas Papyanis, "Masses revolutionnaires et directions reformistes: Les Tensions au coeur des grèves des métallurgistes français en 1919," Le Mouvement Social, 93 (1975): 51-73; and Gilbert Hatry, "Les Délégués d'atelier aux Usines Renault," in Patrick Fridenson, ed., 1914-1918, l'autre front: Cahiers du "Mouvement Social", 2 (Paris, 1977): 221-35. Also see the older surveys, Roger Picard, Le Mouvement syndical durant la guerre (Paris, 1927); and William Oualid and Charles Picquenard, Salaires et tariffes, conventions collectives, et grèves: La Politique du Ministère de l'Amament (Paris, 1928)'.

${ }^{17}$ On Britain, in addition to Hinton's The First Shop Stewards' Movement, see Branko Pribicevic, The Shop Stewards' Movement and Workers' Control (Oxford, 1959); Arthur Marwick, The Deluge (New York, 1970), 56-76, 20309; and G. D. H. Cole, Labour in the Coal-Mining Industry, 1914-21 (Oxford, 1923). On Germany, see Eberhard Kolb, Die Arbeiterräte in der deutschen Innenpolitik, 1918-1919 (Düsseldorf, 1962), and "Rätewirklichkeit und Räte-ideologie in der deutschen Revolution von 1918-1919," in Kolb, ed., Vom Kaiserreich zur Wermarer Republik (Cologne, 1972), 165-84; Reinhard Rürup, ed., Arbeiter- und Soldatenräte im rheinisch-westfälischen Industriegebiet (Wuppertal, 1975); Peter von Oertzen, Betriebsräte in der Novemberrevolution (Düsseldorf, 1963); Erhard Lucas, Märzrevolution im Ruhrgebiet, vol. 1 (Frankfurt a/M, 1970), and Märzrevolution 1920, vol. 2 (Frankfurt a/M, 1973); and Georg Eliasberg, Der Ruhrkrieg 1920 (Bonn, 1974).
} 
struggle to speak for labor. Bourgeois politicians such as David Lloyd George in 1919 or Giovanni Giolitti in 1920 deflected protests into cumbersome committees, which finally generated compromise proposals for co-determination that commanded no adherence and were soon shelved (much like the recent Bullock Commission in Britain). Supple industrial leaders, such as Milanese banker and electrical magnate Ettore Conti or Rhenish lignite industrialist Paul Silverberg, similarly exploited such spurious concessions. ${ }^{18}$

Still, given the limitations of the movement, the council episodes suggested that bourgeois concepts of rational economic and political authority were all terribly vulnerable. The dramas staged at Fiat or Renault or the mines of Essen were frightening not primarily because they may have attained an ephemeral success but because they suggested that only force, not consensus, stood in the way of a collectivist alternative. At stake, therefore, was bourgeois legitimacy as well as naked control. Bourgeois response, thus, had to go beyond mere repression. Counterstrategies had to operate on plant and national planes, micro- and macro-levels simultaneously. The need to reassert authority within the factory gave renewed impetus to plans for scientific management, which would further centralize factory authority by differentiating tasks "down to the tiniest detail," as some French sponsors defined their Taylorite efforts. ${ }^{19}$

Acceptance of this technocratic functionalism required conservative flexibility, and business as well as political milieux divided between progressives and reactionaries. The reactionaries distrusted industry-wide organization and insisted on the prerogatives of ownership, asserting what the Germans called their Herr-im-Hause domination. But the more fruitful approach was to build upon the potential for cooptation that wartime labor-management agreements and the unavowed brotherhood of wage-price spirals had encouraged after $1914{ }^{20}$ As might be expected, the industrial "progressives" were less fixated on ownership, more concerned with managerial expertise; they were multi-divisional foxes rather than single-factory lions. Building upon his wartime organizational efforts, Walther Rathenau forcefully defended entrepreneurial leadership, while outlining complex schemes for capitalist self-government and planning. Later in the decade, Alfred Mond, organizer of the Imperial Chemical cartel and Ernest Mercier, an architect of French electrical networks, pursued related visions (as did Herbert Hoover in the United States). ${ }^{21}$ Other spokesmen throughout the

\footnotetext{
${ }^{18}$ See Charles S. Maier, Recasting Bourgeois Europe (Princeton, 1975), chap. 3.

19 "Concours pour l'application du Système Taylor dans les Mines et Usines de la Société de Pont-à-Mousson: Préamble," PAM, box 18936.

${ }^{20}$ Gerald Feldman, "German Business between War and Revolution: The Origins of the Stinnes-Legien Agreement," in Gerhard A. Ritter, ed., Entstehung und Wandel der modernen Gesellschaft: Festschrift für Hans Rosenberg zum 65. Geburtstag (Berlin, 1978), 312-41, and Iron and Steel in the German Inflation, 1916-1923 (Princeton, 1977), 91; Charles A. Gulick, Austria from Habsburg to Hitler, 2 vols. (Berkeley and Los Angeles, 1948), 1: 150-57; and Charles S. Maier, "The Politics of Inflation in the Twentieth Century," in Fred Hirsch and John Goldthorpe, eds., The Political Economy of Inflation (Cambridge, Mass., 1978), 49-52.

${ }^{21}$ Walther Rathenau, Von kommenden Dingen (1916), and Die neue Wirtschaft (1917), volumes 2 and 3 of his Gesammelte Schriften (Berlin, 1918); Alfred Moritz Mond, Industry and Politics (London, 1927); Hector Bolitho, Alfred Mond, First Lord Melchett (London, 1933), 313-18; and Richard Kuisel, Ernest Mercier, French Technocrat (Berkeley and Los Angeles, 1967). Also $\rightarrow$ Martin Fine, "L'Association Française pour le Progrès Social (1927-1929)," Le Mouvement Social, 94 (1976): 3-29.
} 
1920s derived from the important interindustry associations-less businessmen than their organizers and lobbyists: François Poncet of the Comité des Forges with his sleek defense of technocratic inequality; Gino Olivetti of Confindustria, who from even before the war was to emphasize that only the industrialist could "technically order the factory according to a pre-established plan"; his successor Antonio Benni, who insisted that industry was "not personified by the capitalist or the stockholder but by its directors, by its chiefs, and by the organizers of the enterprise." 22 Industry, moreover, became the paradigm for political society in general, as, for instance, when Ernest Mercier sought to rally managerial expertise in the above-party Redressment Français or Alfred Mond organized the Mond-Turner talks with trade-union leaders in the wake of the British General Strike.

These initiatives and self-justifying notions were hardly widespread enough to reorder industrial organization, any more than the council movement had revolutionized the workplace. Nonetheless, celebrators and critics alike felt that scientific management represented a decisive economic and social breakthrough, ${ }^{23}$ and the economic circumstances of the late 1920s powerfully reinforced this new legitimation of capitalism. The stabilization of currencies on the gold-exchange standard, renewal of intense international competition, and concern about saturation of home markets all made "rationalization" more urgent. Rationalization was a concept that comprised market-sharing agreements across frontiers and within domestic economies plus parallel efforts to lower the burden of wages and other costs through investment, technical improvements, and mergers. At the same time industrial leaders sought legitimation for their power, whether it derived from the right to lay off workers in a cyclical downturn or from their collaboration with an authoritarian regime as in Italy. The managerial mystique evoked widespread enthusiasm, assumed a truly cultic importance precisely because it was a modern and supposedly class-neutral alternative to the immediately preceding socialist attack on industrial hierarchies.

"This Taylorization is connected with the problem of lowering overall costs," noted Marcel Paul, a Pont-à-Mousson manager, when his firm embarked upon the venture in the late $1920 \mathrm{~s}^{24}$ Scientific management supposedly promised a painless method of cost cutting, although it often just meant speed-ups or extra

${ }^{22}$ André François Poncet, Reflexions d'un républicain moderne (Paris, 1925); Olivetti, as quoted in Franklin Adler, "Factory Councils, Gramsci, and the Industrialists," Telos, 31 (1977): 79; and Benni, as quoted in Maier, Recasting Bourgeois Europe, 567. Also see Franklin Adler, "Italian Industrialists and Radical Fascism," Telos, 30 (1976-77): 193-201.

${ }^{23}$ For Andre Philips's analysis of the central role of scientific management in American economic achievement, see his Le Probleme ouvrier aux Etats-Unis (Paris, 1927). For the enthusiasm evoked by what I call the "managerial mystique," see Edmond Giscard d'Estaing, "Le Néocapitalisme," Revue des Deux Mondes, August 1, 1928; Paul Devinat, Scientific Management in Europe, ILO Studies and Reports, ser. B, no. 17 (Geneva, 1927); and La Prospérité: Revue trimestrielle de l'organisation scientifique (1928-), an ebullient magazine that was briefly published by Michelin.

${ }^{24}$ Marcel Paul to Jean Cavalier, May 19, 1928, PAM, box 41595. On the thrust of rationalization, see Robert Brady, The Rationalization Movement in German Industry (Berkeley and Los Angeles, 1933); Giulio Sapelli, "L'Organizzazione 'scientifica' del lavoro e innovazione tecnologica durante il fascismo," Italia Contemporanea, 28 (1976): 3-28; and Paola Fiorentini, "Ristrutturazione capitalistica e sfruttamento operaio in Italia negli anni '20," Rivista Storica del Socialismo, 10 (1967): 134-54. 
hours. The unions, however, had already exhausted their capacity for resistance during fruitless labor struggles, in France during 1920, in Italy from 1920 through 1922 and less overtly in 1924-26, in Germany after the inflation and again by 1928, and in Britain during 1921 and 1926. By the late 1920s, moreover, a generation of moderate labor spokesmen emerged who honestly believed in collaboration: trade unionists in Germany and the United States, the aging Albert Thomas at the Geneva International Labor Office, the younger Walter Citrine, and Ernest Bevin, who saw his job of "the large scale organization of labor" as akin to that of the industrial manager. ${ }^{25}$

The Left never again challenged the premise that production was a question for managers and engineers with the same vigor that they had immediately after the first war. Even when the close of World War II seemed to offer renewed opportunity, plans to reorganize the factory and control production remained relatively undeveloped. In France, workers revolted against the coerciveness of the Occupation and sought to oust patrons they identified as both collaborators and exploiters. But their efforts yielded only limited success, and the bitterness of the later strikes in 1947 and 1948 testified to the frustration of aspirations raised at the Liberation. The Communists did support new schemes for a workers' voice in the tripartite management boards (representing management, labor, and the state) for the nationalized industries, urged by Minister of Industry Marcel Paul. But they had to retreat in the face of MRP and Socialist countermeasures to ensure a more technical supervision; nor was it clear that the PC had really wanted more than its own industrial barony. ${ }^{26}$ Italian workers were perhaps most consistent in reviving factory representation through the consigli di gestione. Communist spokesmen, however, came to define these councils as a structure for giving the workers a stake in production. They were not intended to replicate Gramsci's revolutionary factory councils. ${ }^{27}$ And, in Germany, while co-determination as sought in the mining and metal industries may well have represented a creative and innovative demand, it still remained an effort more to share in the control of traditional managerial functions rather than to overthrow them. The left-wing SPD spokesman Viktor Agartz developed the most

\footnotetext{
25 "The opposition of leaders of labor to bonafide scientific management has practically disappeared, and during recent years there has been noteworthy cooperation between scientific management leaders and labor leaders"; H. S. Person, "Scientific Management," Industrial Relations Committee Report, February 15, 1928, AFL Papers, Florence Thorne Collection, 117/8A, box 18, State Historical Society of Wisconsin, Madison, Wisc. Also see Milton J. Nadworny, Scientific Management and the Unions, 1900-1932 (Cambridge, Mass., 1955); Philips, Le Problème ouvrier aux Etats-Unis, 556; Martin Fine, "Albert Thomas: A Reformer's Vision of Modernization, 1914-1932," Journal of Contemporary History, 12 (1977): 545 $\rightarrow$ Madeline Rebérioux and Patrick Fridenson, "Albert Thomas, pivot du reformisme français," Le Mouvement Social, 87 (1974): 85-97; and Alan Bullock, The Life and Times of Emest Bevin, volume 1: Trade Union Leader, 1881-1940 (London, 1960), 396.

${ }^{26}$ See Etienne Dejonghe, "Les houillères à l'épreuve, 1944-1947," Colloque de Lille, in Revue du Nord, 57 (1975): 643-66. On nationalization schemes, see Mario Einaudi et al., Nationalization in France and Italy (Ithaca, N.Y., 1955), 96-105.

${ }^{27}$ For Emilio Sereni's exhortation, see Guizzi, "La Fabbrica italiana Magneti Marelli," 252; and, on the role of post-1945 councils, see Paride Rugafiori, "La 'Ricostruzione' in una grande azienda IRI in crisi: L'Ansaldo (1945-1948)," in Ganapini et al., La Ricostruzione nella grande industria, 428-444; and Giulio Sapelli, "Industriali e lotta di classe a Torino (1945-1947)," ibid., 445-527. Also see Liliana Lanzardo, Classe operaia e partito comunista alla Fiat: La Strategia della collaborazione (Turin, 1971). For a good survey, see F. Levi et al., Il Triangolo industriale tra ricostruzione e lotta di classe, 1945-1948 (Milan, 1974).
} 
extensive concepts of "economic democracy" but quickly declined in influence in his own party once the Federal Republic was constituted.$^{28}$ In short, the second postwar era did not resume the fundamental ideological challenge to managerial control of twenty-five years earlier. The first postwar restoration had largely confirmed the premise that the modern industrial order must operate under hierarchical chains of command, like an army or bureaucracy. The presumption of technical rationality legitimized the economic power that ownership alone could not.

SUBDUING LABOR'S BID to control the organization of production and, by extension, to make economic authority democratic was not sufficient, however, to stabilize a political economy that faced great inherent strains after the First World War. If the defenders of interwar capitalism proposed a social bargain-the increasing satisfaction of material wants in return for a restoration of industrial authority-they had to be able to pay up. In the interwar period, however, many difficulties precluded paying up for more than a brief period.

Two interlocking flaws especially undermined sustained prosperity: constraints imposed by the international economy and by domestic conflicts. Once currencies were stabilized under the gold-exchange standard, balance-of-payment concerns, especially in light of the postwar creditor position of the United States, seemed to mandate relatively low European wages so that Britain and the Continent could maintain exports, compete internationally, and preserve their exchange rates. Reparation obligations for Germany and war debts for the Allies just made these constraints more demanding. At the same time, within each country, economic leaders remained preoccupied with potential saturation of the market and limits of profitability-what the Germans term Rentabilität. Industry spokesmen felt that profits were faltering, capital accumulation and investment was imperiled, and, in turn, international competitiveness endangered. They sharply attacked what they perceived as the politically determined costs of labor and of new social-insurance obligations. ${ }^{29}$

But, while European businessmen fretted about impediments to accumulation, the relatively high rates of investment in the late 1920s may have outpaced the purchasing power that would sustain the return to capital. Although wages may not have lagged proportionally behind returns to capital, ${ }^{30}$ urban and rural disposable incomes did not necessarily grow sufficiently to justify the continued "rationalization" of the 1920s. In formal terms, what had to be attained was a "warranted growth" path of capital and incomes that allowed the expansion of each to call forth and absorb the increments of the others. Only satisfying the

\footnotetext{
${ }^{28}$ Ernst Ulrich Huster, Die Politik der SPD, 1945-1950 (Frankfurt a/M, 1978), 35-41. Also see Erich Potthoff, Der Kampf um die Montanmitbestimmung (Cologne, 1957); and Eberhard Schmidt, Die verhinderte Neuordnung, 1945-1950 (Frankfurt a/M, 1970), 182-200.

${ }^{29}$ For the best recent discussion of these attitudes in Germany, see Bernd Weisbrod, Schwerindustrie in der Weimarer Republik (Wuppertal, 1978).

${ }^{30}$ Peter Temin has insisted on this, for the U.S.-European indices can be read in different ways; Temin, Did Monetary Forces Cause the Great Depression? (New York, 1976), 32.
} 
two constraints together allowed each to be resolved in its own right. Only securing the two simultaneously, moreover, was likely to reconcile the major organized interest groups of the European economies.

Reading backward, one can say, of course, that the 1930s did not find the warranted growth path; and the original statements of the difficulty reflected the somber outcome in their pessimistic depiction of a "knife edge" that a dynamic economy had to tread if it was not to falter. Later theory, perhaps reflecting the generation of post-1950 growth, has suggested that in fact equilibrium growth is relatively easy to generate: technological substitutions, public spending, population growth, and income redistribution have all been shown to make ascent of the knife edge far less chancy. ${ }^{31}$ Indeed, the dilemma of equilibrium growth at the end of the 1920s was in part self-imposed by the reigning preoccupation with capital shortages and by the brakes placed on national income growth by the neomercantilist policies of the years following currency stabilization. There were dissenters to prevailing policy, such as John Maynard Keynes. But Keynes remained a gadfly and not always consistent in his recommendations. By the 1930s Keynes and like-minded adherents of purchasing-power doctrines pointed to the state as the agency that could assure high aggregate demand. Their intellectual task became simplified when they urged that their societies more or less disconnect from the international market and seek higher employment levels autarkically-that is, that they cease to fret about exchange rates. Indeed, abandonment of old currency parities followed almost by force majeur after 1931. In the long run, Keynes also felt, capital accumulation should become a less preoccupying task, for capital would become more plentiful in relation to the need for it. ${ }^{32}$

Today these simplifying premises appear more problematic. Indeed, contemporary Western economic dilemmas suggest partial parallels with the difficulties perceived at the end of the 1920s. United States economic concepts for the postwar international economy largely precluded the welfare-state self-sufficiency that Keynes suggested. This meant further that his vision of satiated investment needs, with its resultant "euthanasia of the rentier," was likewise premature. Industrial societies in a world market arena can hardly allow investment to atrophy without losing real income to new competitors. Even to apply Keynesian macroeconomic stimulus to assure full employment may bring deteriorating balances of trade and, if no foreign subsidies are found, declining welfare. Some

\footnotetext{
${ }^{31}$ For the "knife-edge view" of the warranted growth path, see R. F. Harrod, "An Essay in Dynamic Theory," Economic Journal, 49 (1939): 12-33, 377. Also see Evsey D. Domar, "Capital Expansion, Rate of Growth, and Employment," Econometrica, 14 (1946): 137-47. James Tobin and Robert M. Solow allowed for various tenable rates of growth with factor substitutability; see Tobin, "A Dynamic Aggregative Model," Journal of Political Economy, 63 (1955): 103-15; and Solow, "A Contribution to the Theory of Economic Growth," Quarterly Journal of Economics, 70 (1956): 65-94. For a recent optimistic summary that sees supply normally generating demand (with the 1930s as an exceptional catastrophe), see John Cornwall, Growth and Stability in a Mature Economy (London, 1972).

32 For Keynes's views concerning the decreasing scarcity of capital, see his The General Theory of Employment, Interest, and Money (London, 1960), 375-77; and, concerning the advantages of going it alone, see his Essays in Persuasion (1931; 2d ed., New York, 1963), 271-96, and "National Self-Sufficiency," New Statesman and Nation, July 8, 15, 1933.
} 
of the constraints that vexed the 1920s have thus re-emerged and, with them, the distributive conflicts between the interests of wage earners and the spokesmen for capital. The difference is that, in the 1920s, the difficulties were rooted in too limited a confidence in mass consumption as a force for growth, whereas in the 1970s they may have derived from too excessive a reliance.

What remains historically remarkable is that from the late 1940s into the 1970 s the constraints of the interwar period eased as a twin reorientation took place. First, the United States developed a commitment to European prosperity; second, the political and economic calculations of Europeans themselves changed so that they felt less locked into a distributive contest. Both changes together eased the iron framework of wages, profits, state claims, and international payments. ${ }^{33}$

How could this reorientation take place so easily after 1945 ? For one thing, it was silently underway before that date. The Depression had certainly discredited the old orthodoxies. The war also demonstrated to British and American financial planners that states could impose levels of expenditure far beyond what the budget-balancers of the 1920s or British Treasury officials of the 1930s had imagined was safe and feasible. ${ }^{34}$ Certainly the role of the United States was transformed: the credits of the 1920s had been extended via private banks and had remained hostage to the differential rates of return in Europe and New York; the grants of the late 1940s represented political decisions on the part of Washington. The new American policy did not come instantaneously or automatically. Just as between 1922 and 1924 the New York banking community accepted the need to intervene in Europe, so, as the newly opened records of the U.S. National Advisory Council on International Monetary and Financial Policies help show, Washington became increasingly willing to exploit foreign aid for political purposes: from the coy hesitation about extending loans to the Léon Blum mission in early 1946, to the vigorous European Recovery Program and the almost importuning support for noncommunist unions and parties by 1948 , to the funds rushed to Yugoslavia after Tito's break with the Cominform. ${ }^{35}$

The Marshall Plan signaled a political decision that the resources of the United States would be available for the reconstruction of a welfare capitalism in Europe. But in quantitative economic terms American aid amounted to little.

\footnotetext{
${ }^{33}$ The conflict between international competitiveness and demand stimulus at home has been brought out especially by the "Scandinavian" models of two-sector open economies. See Odd Aukrust, "Inflation in the Open Economy: A Norwegian Model," in Walter S. Salant and Lawrence B. Krause, eds., Worldwide Inflation: Theory and Recent Experience (Washington, 1977), 107-53; and Jeffrey Sachs, "Wages, Profits, and Macroeconomic Adjustment: A Comparative Study," Brookings Papers on Economic Activity, 2 (1979): 269-319.

${ }^{34}$ On the fiscal conservatism of the Treasury, see R. A. C. Parker, "Economics, Rearmament, and Foreign Policy: The United Kingdom before 1939-A Preliminary Study," Joumal of Contemporary History, 10 (1975): 637-47; Robert Paul Shay, Jr., British Rearmament in the Thirties: Profits and Politics (Princeton, 1977), 73-79, 136-55, 242-46; and Susan Howson, Domestic Monetary Management in Britain, 1919-38 (Cambridge, 1975), 12026. For the transformation of attitudes, see Donald Winch, Economics and Policy: A Historical Survey (London, 1972), chap. 12; and Herbert Stein, The Fiscal Revolution in America (Chicago, 1969), chap. 8.

${ }^{35}$ Minutes of the Meetings of the National Advisory Council on International Monetary and Financial Policies, meetings 23, 24 (May 6, 1946), 89 (March 18, 1948), 112 (December 3, 1948, on Japan), 115-16 (January $7,13,1949)$, etc., Office of the Secretary of the Treasury, NA-RG 56.
} 
For the major European economies from 1948 through 1951 it probably contributed no more than 10 to 20 percent of capital formation during the first two emergency years, then tapered off to below 10 percent. ${ }^{36}$ Washington's assistance served more as capital-liberating than as capital-transfusing. "The basic elements in Western Europe's economic crisis ...," the staff of the EatonHerter Select Committee on Foreign Aid accurately emphasized, "converge and appear in their most conspicuous aspect as a deficit in the balance of payments with the dollar area." ${ }^{\prime 37}$ By easing balance-of-payments constraints and freeing key bottlenecks for specific goods, American aid allowed the European economies to generate their own capital more freely, certainly without returning to the deflationary competition of the 1930s. U.S. aid served, in a sense, like the lubricant in an engine-not the fuel-allowing a machine to run that would otherwise buckle and bind.

This calculation suggests that a modulated judgment on the role of American capital would be appropriate. Ultimately, the real sources of Europe's postwar

${ }^{36}$ The following table provides the ratio of grants and loans made by the the United States to the gross domestic capital formation of the respective countries. Gross domestic capital formation (converted here into dollars at current exchange rates) is a more relevant measure for the postwar years than net investment, for the replacement of depreciated plants meant qualitative improvement. (For Italy in 1948 and 1949, only net figures are available.) Grants extended during 1948 comprised largely "interim aid" as a stop-gap before Marshall Plan funds strictly speaking came on stream. After 1951, Marshall Plan aid was phased into Mutual Security assistance with major military components.

\begin{tabular}{|c|c|c|c|c|}
\hline Country & 1948 & 1949 & 1950 & 1951 \\
\hline \multicolumn{5}{|l|}{ UNITED KINGDOM } \\
\hline$\frac{\text { U.S. Aid }}{\text { GDCF in } \$}$ & $\frac{\$ 937 \mathrm{~m}}{\$ 10,400 \mathrm{~m}}=9 \%$ & $\frac{\$ 1,009 \mathrm{~m}}{\$ 9,000 \mathrm{~m}}=11 \%$ & $\frac{\$ 629 \mathrm{~m}}{\$ 6,400 \mathrm{~m}}=10 \%$ & $\frac{\$ 129 m}{\$ 6,300 m}=2 \%$ \\
\hline \multicolumn{5}{|l|}{ FRANCE } \\
\hline$\frac{\text { U.S. Aid }}{\text { GDCF in } \$}$ & $\frac{\$ 781 \mathrm{~m}}{\$ 5,600 \mathrm{~m}}=14 \%$ & $\frac{\$ 766 \mathrm{~m}}{\$ 6,400 \mathrm{~m}}=12 \%$ & $\frac{\$ 465 \mathrm{~m}}{\$ 4,460 \mathrm{~m}}=10 \%$ & $\frac{\$ 421 \mathrm{~m}}{\$ 5,380 \mathrm{~m}}=7 \%$ \\
\hline \multicolumn{5}{|l|}{ WESt GeRMANY } \\
\hline$\frac{\text { U.S. Aid }}{\text { GDCF in } \$}$ & $\frac{\$ 1,130 \mathrm{~m}}{\$ 3,600 \mathrm{~m}}=31 \%$ & $\frac{\$ 948 \mathrm{~m}}{\$ 4,340 \mathrm{~m}}=22 \%$ & $\frac{\$ 470 \mathrm{~m}}{\$ 4,400 \mathrm{~m}}=11 \%$ & $\frac{\$ 362 \mathrm{~m}}{\$ 5,300 \mathrm{~m}}=7 \%$ \\
\hline \multicolumn{5}{|l|}{ ITALY } \\
\hline$\frac{\text { U.S. Aid }}{\text { GDCF in } \$}$ & $\frac{\$ 399 \mathrm{~m}}{\$ 1,500 \mathrm{~m}}=27 \%$ & $\frac{\$ 437 \mathrm{~m}}{\begin{array}{c}\$ 1,300 \mathrm{~m} \\
\text { (net) }\end{array}}=34 \%$ & $\frac{\$ 257 \mathrm{~m}}{\$ 2,700 \mathrm{~m}}=10 \%$ & $\frac{\$ 261 \mathrm{~m}}{\$ 3,000 \mathrm{~m}}=9 \%$ \\
\hline
\end{tabular}

NOTE: All figures in millions of current (1948-51) dollars; only net figures are available for Italy in 1948 and 1949 , and only an estimate can be made for West Germany in 1948, since the available statistics do not give figures for the first half of that year.

SOURCES: Totals of American aid have been taken from Statistical Abstract of the United States, 1954, 898-902; British GDCF, from Statistical Abstract for the United Kingdom, no. 87 (1938-49): Table 294, no. 88 (1950): Table 296, and no. 89 (1952): Table 288; and, other 1948-49 statistics, from Statistisches Jahrbuch für die Bundesrepublik Deutschland, 1952, 454-55; Annuaire Statistique de la France, 59 (1952): 335; and Annuario Statistico Italiano, ser. V, 3 (1951): 590. Non-British GDCF estimates for 1950 and 1951 are taken from United Nations, Yearbook of National Accounts Statistics (1957).

${ }^{37}$ U.S. Congress, House Select Committee on Foreign Aid, Final Report on Foreign Aid (May 1, 1948), 80th Cong., 2d sess., House Report no. 1845, p. 24. 
growth had to derive from the Continent's own energies. Indeed, some recovery was apparently already underway by late 1946, even for the battered West German economy. ${ }^{38} \mathrm{Had}$ not the fearsome winter of 1946-47 paralyzed transportation, impeded food and fuel deliveries, and radicalized workers into politically explosive wage demands, recovery might have continued. In that case, without the emergency American response the ongoing European economic performance might well have resembled, say, British growth in the late 1930s: more protectionist and less spectacular than was to be racked up under American auspices in the $1950 \mathrm{~s}$, but still respectable.

In this regard, the American economic role in restabilization after World War II paralleled the political role. Europe would probably not have "gone Communist" or collectivist even if the United States had not intervened with the same resolution. The European middle classes remained socially anchored; the German occupation had hardly struck or aimed at them as a group, nor had it attacked their economic values. But both the political and economic development of the 1950s would doubtless have been less resolutely capitalist and market-oriented, less justified by dynamic success. Throughout the first three postwar years, in fact, there was less decisive purpose than confused experimentation and uncertain initiatives. Business recovery was not held back by ideological sympathies for socialism but by the fear of risky venture, the hesitation finally to write off the losses of the war years. Between 1945 and late 1947, for example, the French and the Italians, then the West Germans along with their American occupiers, avoided imposing the deflationary reforms that helped invigorate capitalist growth. ${ }^{39}$ Nor were they prepared to abandon the fuzzy political compromises, which found expression in the tripartite Catholic-Socialist-Communist governing coalitions but seemed less and less likely to mandate either socialism or renewed capitalist growth. Only in 1947-48, when ideological and economic threats appeared potentially catastrophic, did the spokesmen for West Europe's middle classes and elites, and their American sponsors, resolve upon the liberal capitalist mandate that might best be described as a new "wager upon the strong."

Economic analysts have proposed several theories for the remarkable growth that followed. Structural explanations include the sharp increase in agricultural productivity achieved by tractors and fertilizers, the resultant supply of labor released for industry (a supply already augmented by the migrants from eastern Germany and the Italian South, among other areas), and the special efficiency

\footnotetext{
${ }^{38}$ Werner Abelshauser, Wirtschaft in Westdeutschland, 1945-1948 (Stuttgart, 1975), 167-70.

${ }^{39}$ For the French rejection of deflation, see Richard Kuisel, Modermization and the Managed Economy: The State and Capitalism in France, 1900-1950 (Cambridge University Press, forthcoming), chap. 7. For the Italians, who in 1947 embarked upon deflation, see George H. Hildebrand, Growth and Structure in the Economy of Modern Italy (Cambridge, Mass., 1965), chaps. 2, 8; Marcello De Cecco, "Sulla politica di stabilizzazione del 1948," in his Saggi di politica monetaria (Milan, 1968), 109-41; and Camillo Daneo, La politica economica della ricostruzione, 19451949 (Turin, 1975), chap. 7. On the American and German hesitation to impose early currency reform, see Edward A. Tennenbaum, "The German Mark," book draft, chaps. 11-12, Tennenbaum Papers, box 3, folder 5, Truman Library, Independence, Mo. Belgium was the outstanding exception to the general inflationary languor at the end of the war. For the reforms of Camille Gutt, see Léon H. Dupriez, Monetary Reconstruction in Belgium (New York, 1947).
} 
of investment in the context of postwar damage and renewal. Monetarist accounts attribute success to rigorous stabilization programs in Germany, Italy, and Japan. The historian can point to the wage restraint that Dutch, German, and Italian workers demonstrated because of labor's commitment to reconstruction and, perhaps, to mere exhaustion after fascist repression and war. ${ }^{40}$ On the managerial side, new business confidence and technocratic impulses gradually prevailed. The example of Pont-à-Mousson suggests that once public policymakers, such as Jean Monnet or Robert Schuman, made commitments to supranational institutions, a new generation of expansionist entrepreneurs could find support for pressing vigorous investment plans within their own firms. ${ }^{41}$

The upshot was that both the major restraints that had corseted the economy of the 1920s could be loosened together. U.S. aid helped overcome the deflationary pressures resulting from defense of the balance of payments. But these pressures also remained minimal because a new generation of Keynesian-influenced administrators were willing to take international deficits in stride. Establishment of European-wide clearance schemes and the willingness of intra-European creditor countries, such as Belgium and even Italy, to hold sterling or other European currencies as a quid pro quo for American aid also eased the strains on the economies tending toward balance-of-payments deficits. Washington policymakers certainly did not like the impediments to currency convertibility that Europeans kept in force, and they continued to press for the removal of these obstacles to the free circulation of dollars. U.S. Treasury officials and American delegates to the International Monetary Fund insisted stubbornly on convertibility even at the cost of deflationary policies. In contrast, American officials with the Marshall Plan administration (the ECA) tended to accept compromise arrangements that permitted Europeans to prolong shielding their international accounts; and even the stern Treasury disciplinarians had to accept British cancellation of sterling convertibility after the disastrous attempt during the summer of 1947. They likewise were compelled to acquiesce in French creation of a two-tiered currency market in 1948, which allowed scope for floating exchange rates, and they accepted restrictions upon full convertibility in the European clearance unions from 1949 through 1951. Preaching that all currencies should be fully tradable for dollars, Washington officials nonetheless lived with a compromise monetary regime. ${ }^{42}$

\footnotetext{
${ }^{40}$ For examples of structural approaches, see Ingvar Svennilson, Growth and Stagnation in the European Economy (Geneva, 1954); U.N. Economic Commission for Europe, Economic Survey of Europe in 1961, part 2: Some Factors in Economic Growth in Europe during the 1950's (Geneva, 1961); and Charles Kindleberger, Europe's Postwar Economic Growth: The Role of Labor Supply (Cambridge, Mass., 1967). For an example of the monetarist approach, see Hildebrand, Growth and Structure in the Economy of Modern Italy. Angus Maddison has emphasized policy factors, including a Western internationalism attributed to the Cold War; see his "Economic Policy and Performance in Europe, 1913-1970," in Carlo Cipolla, ed., The Fontana Economic History of Europe, 5 (Glasgow, 1976): 442-508. For a general treatment, see M. M. Postan, An Economic History of Western Europe, 1945-1964 (London, 1967).

${ }^{41}$ See, for example, the debate on expansion of coking facilities and Roger Martin's advocacy of investment, October 16, 1951, PAM, box 70671. Also see Richard Kuisel, "Technocrats and Public Policy: From the Third to the Fourth Republic," Joumal of European Economic History, 2 (1973): 53-99.

${ }^{42}$ For debates on convertibility, see Minutes of the Meetings of the National Advisory Committee on Inter-
} 
The second major inhibition that had undermined continuing expansion in the 1920s also disappeared: the precarious "knife edge" equilibrium growth path for wages and investment broadened into an easy highway. If policymakers no longer wished to sacrifice living standards on the altar of fixed exchange rates, labor showed sufficient wage restraint such that investment could soar. Rather than relatively high labor costs impelling capital substitution, relatively low labor costs permitted capital expansion. The statistics of the 1950s reveal not only the familiar growth of national income but unprecedented rates of capital formation as well: 30 percent in Japan, 27 percent in Germany, 20 percent in France and Italy, 16 percent in the United Kingdom, 18 percent in the United States. ${ }^{43}$ In contrast, the wages share of national income remained stable or even dropped slightly, as in Western Germany: a decade's halting of the slow but otherwise prevailing trend of the twentieth century. The expansion and harmony that businessmen had sought in the 1920s was finally achieved in the 1950s.

This result, of course, required the cooperation of those labor leaders who shared the premises of a growth-organized welfare capitalism - the commitment that I have elsewhere termed the "politics of productivity." "The improvement of productivity, in its widest sense, remains the fundamental problem of Western Europe," declared the Organization for European Economic Cooperation, and it echoed the themes of the managerial mystique of the 1920s as it reported, "Great emphasis is placed in the United States ... upon public relations efforts by management in acquainting workers with their plant, its problems, and its place in the economy." ${ }^{\prime 45}$ For society as a whole, the politics of productivity meant simply the adjournment of conflicts over the percentage share of national income for the rewards of future economic growth. As one West German official explained to business and labor representatives in the remarkable Königstein discussions of February 1949 (which, in effect, adumbrated West German economic strategies up to the present day), anyone who could renounce some consumption had to renounce it. "He had to save, whether or not he wanted, because he cannot be permitted to evade the common tasks of reconstruction." 46

national Monetary and Financial Policies, meetings 70, 79-81, 83-84, 134, 153, 158, 171, Office of the Secretary of the Treasury, NA-RG 56. For the EPU, see William Diebold, Jr., Trade and Payments in Western Europe (New York, 1972), 64-69; and Albert O. Hirschman, "The European Payments Union: The Negotiations and the Issues," Review of Economics and Statistics, 33 (1951): 49-59.

${ }^{43}$ Simon Kuznets, Modern Economic Growth: Rate, Structure, and Spread (New Haven, 1966), 236-37; and U.N. Economic Commission for Europe, Some Factors in Economic Growth in Europe during the 1950's, chap. 2, pp. 1622. For the wage share ố national income, see U.N. Economic Commission for Europe, Incomes in Postwar Europe: A Study of Policies, Growth, and Distribution (Geneva, 1967), chap. 2, pp. 30-31.

${ }^{44}$ See my "The Politics of Productivity: Foundations of American International Economic Policy after World War II," in Peter Katzenstein, ed., Between Power and Plenty: The Foreign Economic Policies of Advanced Industrial States (Madison, Wisc., 1978), 23-49; the articles in this volume were first published in 1977, as the autumn issue of Intemational Organization.

${ }^{45}$ Organization for European Economic Co-Operation [hereafter, OEEC], Europe: The Way Ahead: Towards Economic Expansion and Dollar Balance, 4th Annual Report of the OEEC (Paris, 1952), 195. Also see Roger Grégoire, "European Productivity Agency," in OEEC, At Work for Europe (5th ed., Paris, 1960), 139-52.

${ }^{46}$ Statement of Dr. Troeger, Königstein, January 4, 1949, BA Koblenz, Z 13/63. The labor minister of the Bizone, Halbfell, dissented, arguing against unplanned investment, but was in a clear minority. 
As an explicit principle of consensus, economic growth-the notion of continuously higher levels of national product - came into its own at the end of the 1940s. The earliest public celebration of its virtues may well have been Leon Keyserling's speeches as chairman of the Council of Economic Advisers during $1949 ;{ }^{47}$ but the less precise concepts of sustained high purchasing power or simply "reconstruction" or "production" served to rally labor as well as businessmen from the end of the war on.

Throughout 1945 and 1946 Communist labor leaders themselves seemed ready to accept the trade-off between present consumption and future growth. The increasing hardship of their rank and file during the winter of 1946-47 and the threat of militant unions on their left flank (aside from any guidance that Moscow may have urged as the dispute with the United States deepened) impelled them to abandon their collaborative stance. The French Communists' reluctant sponsorship of the Renault strike, which likewise led to their dismissal from the governing coalition (and, similarly, the Belgian Communists' refusal to accept coal price increases), best revealed their shifting priorities. No less anticommunist an AFL representative than Irving Brown, who felt that the successive strikes revealed the Communists' "complete desire to destroy the government even at the cost of permanently destroying France," understood that a socialist movement could hardly recapture leadership within the CGT if it participated in a cabinet seeking to freeze wages. ${ }^{48}$ Despite the admitted difficulty in reconstructing a mass base for the socialists, by 1947-48, American policymakers, AFL emissaries, and European businessmen diligently encouraged the formation of social democratic unions in the Latin countries and pressed for the purge of Communist sympathizers from British, German, and American federations. The moderates of Force Ouvrière, the TUC, or the Italian Catholic union federation (CISL) became all the more essential as interlocutors for labor. "The trend in Europe is clearly toward the Left," noted one of the Department of State's leading European analysts shortly after tripartism collapsed. "I feel that we should try to keep it a non-communist Left and should support Social-Democratic governments. ${ }^{\prime 49}$ The axis of the politics of productivity thus had to fall

\footnotetext{
${ }^{47}$ Keyserling, "Prospects for American Economic Growth," Address in San Francisco, September 18, 1949, Truman Library, President's Secretary's File 143: "Agencies: Council of Economic Advisers."

${ }^{48}$ Brown, "Report on Greece, France, and England," July 7, 1947, State Historical Society of Wisconsin, AFL Papers, Florence Thorne Collection, 117/8A, box 17, F. 3A. On the events of 1947, $\rightarrow$ Wilfried Loth, "Frankreichs Kommunisten und der Beginn des kalten Krieges: Die Entlassung der kommunistischen Minister im Mai 1947," Vierteljahrshefte fuir Zeitgeschichte, 26 (1978): 9-65, and "Die französischen Sozialisten und der Marshall-Plan," in Lutz Niethammer, ed., Die europäischen Linke und der Marshall-Plan (forthcoming). Also see Vincent Auriol, Joumal du Septennat, ed. Pierre Nora and Jacques Ozouf, volume 1: 1947 (Paris, 1970), passim; and Alfred Rieber, Stalin and the French Communist Party, 1941-1947 (New York, 1962), 331-57. On Belgium, see NA-RG 59, 855.00/3-1147 (no. 372), 855.00/3-2147 (no. 1069), 855.00/3-3147 (no. 1097).

49 John Hickerson to H. Freeman Matthews, June 25, 1947, NA-RG 59, Office of European Affairs, box 3. For European policies of the AFL, see International Labor Committee, Minutes of the Meeting of November 11, 1947, AFL Papers, Florence Thorne Collection, 117/8A, box 17, F. 3C. Also see Matthew Woll to Thorne, April 6, 1948, and the attached "Confidential Report," ibid., F. 4. And see Ronald Radosh, American Labor and U.S. Foreign Policy (New York, 1969); Ulrich Borsdorf, "Erkaufte Spaltung: Der Marshall-Plan und die Auseinandersetzung um die deutschen Gewerkschaften," in Niethammer, Die europäischen Linke und der Marshall-Plan; Horst Lademacher, "Die Spaltung des Weltgewerkschaftfundes als Folg des beginnenden Ost-West Konfliktes," ibid.; and Lutz Niethammer, "Strukturreform und Wachstumspakt," in Heinz Oskar Vetter, ed., Vom
} 
right in the center of the labor movement: "politically speaking the break must come to left of or at the very least in the middle of the [French] Socialist party. Translated into labor terms, the healthy elements of organized labor must be kept in the non-Communist camp. Otherwise the tiny production margin of the fragile French economy would vanish and the ensuing civil disturbances would take on the aspects of civil war." 50

The economic premises that the "healthy elements" of labor subscribed to remained precisely those of the trade-union leaders who had pioneered collaborative labor relations in the late 1920s. Union spokesmen such as Ernest Bevin had then joined progressive industrialists for talks on enhancing productivity. By the late 1940 s they were serving in high office. Their integration testified to the postwar years' fulfilment of the second criterion for stabilizing the welfare capitalist economies of the West. The new cooperation, along with America's underwriting, ensured that capital accumulation and wages and welfare benefits could increase in tandem, thus overcoming the fatal impediments to sustained growth in the 1920s. As Western leaders looked more and more to economic growth, increasingly presupposed, first, as automatic and, second, as the major index of a society's welfare, the stakes of politics narrowed. Communism increasingly became a permanent and sullen opposition, to be analyzed, in the spirit of the 1950s, as inherently pathological. At the same time, the appeal of neofascism or Gaullism remained fitful, largely consigned to the regions that paid for dynamic growth elsewhere with their own relative backwardness. In the political center Christian Democrats (or Tories in Britain) either shared power with Social Democrats or alternated officeholding in a consensual politics that debated only whether the anticipated dividends of economic growth should be devoted to social-welfare consumption or ploughed back into private investment. Residual colonial or religious and ethnic issues-not the baselines of political econnomy-remained the major sources of passion and controversy.

Repression, cooptation, and the success of the managerial mystique with its vogue of productivity had reconsolidated the bureaucratic organization of industrial work in the 1920s. The economic accomplishments of the period after 1948 completed the second half of the stabilization assignment. They seemed to eliminate the vulnerability of economic life and enhanced legitimacy with output and growth. Despite the tragic waste of the Great Depression, the immense destructiveness of two world wars, and the countless lives scattered like dry autumn leaves throughout Europe, Western leaders recovered more of their prosperity and liberalism, retained more of their privileges and prerogatives, than they would have dared predict.

\footnotetext{
Sozialistengesetz zur Mitbestimmung: Zum 100. Geburtstag von Hans Böckler (Cologne, 1975), 303-58. On the French unions, see Bergonieux, Force Ouvrière; and André Barjonet, La C.G.T. (Paris, 1968), 49-51. On Italy, see Daniel L. Horowitz, The Italian Labor Movement (Cambridge, Mass., 1963), 208-73; and Adolfo Pepe, "La CGIL dalla ricostruzione alla scissione, 1944-1948," Storia Contemporanea, 5 (1974): 591-636, and the works cited in n. 31. Also see the reports from Paris and Rome to the Department of State in Foreign Relations of the United States, 1947, 3 (Washington, 1972): 690-91, 695-99 (on the CGT), 847-48, 863-68 (on Italian labor).

${ }^{50}$ Robert Lovett to Ambassador Caffrey, Paris (based on a memo by Hickerson), October 25, 1947, NA-RG $59,851.00 / 10-2447$.
} 
SUCCESSFUL SYSTEMS OF POLITICAL EQUILIBRIUM must remain isolated (as did Tokugawa Japan) or be international in scope. The notable eras of European stabilization - the generation after Utrecht, for example, or the half-century after Vienna-have been periods of class equilibrium and international compromise simultaneously. The configurations of power among states tend to second those within societies. The Vienna settlement consisted of adjustments between states but also comprised a restoration of old and new landed classes along with a strengthened bureaucracy. Pax Britannica assimilated bourgeois elements to this international coalition and added resources outside Europe to equilibrate strains at home. Fully to comprehend the period from 1918 to 1950 as a search for stabilization on the part of old upper and middle classes, now augmented by a reformist working-class leadership, requires looking at the international architecture as well as domestic structures. Obviously, the Cold War had a decided influence on internal outcomes after World War II. But to register this connection hardly reveals the principles of interaction. The Cold War did not, in itself, determine the logic of the international system for domestic stability.

The surprising centers of growth in the 1950s and 1960s were West Germany, Japan, and, though a smaller economy, Italy. West Germany and Japan, above all, became virtual engines of capital accumulation. As such, they played a critical role in U.S. encouragement of an international coalition of liberal polities with mixed capitalist economies. Although, as of 1944, the U.S. Treasury resoundingly rejected the idea that a German economic contribution would be vital for European prosperity, Congressmen, the Harriman mission (to prepare for Marshall Plan aid), and industrial leaders by 1947 viewed German recovery as doubly critical, both for its own sake and for the economic linchpinning of the wider region. ${ }^{51}$ If integrated into a West European system of exchange, German skilled labor, technological virtuousity, and coal would benefit all her neighbors. Without German recovery and integration, their economies must operate less efficiently. The same calculation came to hold for Japan and its role in America after the Communist takeover in China and hostilities in Korea. ${ }^{52}$ Opponents of a punitive treatment for Germany had emphasized their European economic vision from the outset, and by the summer of 1947 their concept had quickly become the main theme of the influential spokesmen for German recovery. The lesson was not lost on industrial interests in the emerging state: when German firms petitioned to raise their output or rebuild their rolling mills, their directors

${ }^{51}$ U.S. Treasury Memorandum, "Is European Prosperity Dependent upon German Industry?" September 7, 1944, Mudd Library, Princeton University, Harry Dexter White Papers, box 7, F. 22e: "In short, the statement that a healthy European economy is dependent upon German industry was never true, nor will it be true in the future." For the turnabout, see "Records of Conferences," Harriman mission, summer 1947, W. A. Harriman's papers, Washington, D.C. Also see John Gimbel, The Origins of the Marshall Plan (Stanford, 1976), and The American Occupation of Germany, 1945-1949 (Stanford, 1968), 147-58, 163-69, 174-85.

${ }^{52}$ Joyce Kolko and Gabriel Kolko, The Limits of Power: The World and United States Foreign Policy, 1945-1954 (New York, 1972), chaps. 11, 19; Jon Halliday, A Political History of Japanese Capitalism (New York, 1975), 18290; and John Dower, Aftermath of Empire: Yoshida Shigeru and the Japanese Experience, 1878-1954 (Cambridge, Mass., 1979), chaps. 9-10, and manuscript essays on "The Reverse Course." 
unabashedly pleaded the cause of good Europeans..$^{53}$ Nor was recovery only the demand of businessmen. German trade unions and the AFL, which supported them, strongly advocated industrial reconstruction. ${ }^{54}$ Rehabilitation of the German economy thus emerged as critical for the United States's wager on productivity.

Was it just an accident that the countries that forged ahead so brilliantly and then came to serve as international poles of growth even beyond expectation were the exfascist powers? This question must be confronted, despite its harsh implications. Did Washington, in effect, reap the final benefit from the discipline and coercion of labor that the Axis states had earlier imposed? Not directly, of course. But the American-sponsored international economy may have ultimately benefited from the fact that the working classes within the defeated countries had been atomized by political repression, wartime sacrifices, and the mere tasks of survival. Labor leaders who returned from concealment, prison, or exile faced sufficient challenge just in rebuilding their shattered movements. Stressing the necessity of production appeared to them less a contribution to restoration than the premise for the patient work of reorganization. ${ }^{55}$ In addition, defeat and occupation clearly permitted the United States more direct intervention than was possible elsewhere. Occupation authorities in all three countries could limit the organization of political unions, postpone nationalization, and halt strikes. Allied fiscal control-exerted perhaps most consistently by Joseph Dodge in Japan ${ }^{56}$ - ultimately reinforced those who advocated rapid capital formation, although businessmen often resisted at first. Harder to measure, but just as important, was the yearning for private goals in countries where fascists had sought to politicize all aspirations and relationships. The United States, after all, was gambling on the renewed persuasiveness of individual wellbeing.

Germany, however, had hitherto repeatedly resisted integration into an international productive coalition. Insofar as the international divisions of the period from 1914 to 1950 had an economic dimension, they involved conflict less between capitalist societies and a Bolshevik challenger than among different capitalist alternatives. Anglo-American disagreements over the organization of a global economy persisted and raised bitter recriminations on each side. The issue remained whether the international economy should maximize multilateral

\footnotetext{
${ }^{53}$ See, for example, Akten des Verwaltungsamtes für Eisen und Stahl, BA Koblenz, Z 41/23: "Vorschlag zur Wiedereinschaltung der August Thyssen Hütte in der europäischen Stahlplanung . . 9 Februar 1950."

${ }^{54}$ For example, see the works council of Robert Bosch, AG's protest against decartelization proceedings, March 17, 1948, Deutscher Gewerkschaftsbund Archiv, Düsseldorf: "Wirtschaftspolitik, Dekartellierung 1948-49." For similar objections to controls on German industry, see BA Koblenz, B 109/345: "Stellungnahme der Gewerkschaften zum Ruhrstatut vom 7. Januar 1949." For a specimen of AFL support, see William Green to President Truman, November 24, 1947, AFL Papers, William Green Collection, 117A/11C, box $7 F$ (Marshall Plan).

${ }^{55}$ For an example of this organizational effort, see [Hans Böckler] "Bericht der Deutschlandreise, 6. März bis 30. April 1946," Deutscher Gewerkschaftsbund Archiv, Düsseldorf.

56 Detroit Public Library, Joseph Dodge Papers, Japan Assignment, box 1, F: "Budget: Ikeda Interviews," and Japan Assignment, 1950, box 3, F: "Correspondence, Marquat."
} 
trade and welfare, but thereby reward the most massive and technologically productive economy, or whether as the British desired, it should be based upon regional systems of dominion that guaranteed international markets to the weaker power. ${ }^{57}$ Still, the British dominion alternative seemed to be a limited challenge, whereas the German threat to the open international economy had been more ominous and, just as critical, the emanation of an ugly political regime.

This is not to argue that Nazism was menacing because of its international economic policies - the autarky and bilateralism that so angered Cordell Hull. Instead, the connection between politics and economics was central to the very way Nazism was interpreted as a regime. American commentators viewed Nazism as an abusive political economy: a cartel of monopolists who subordinated the public sphere to private forces. ${ }^{58}$ Although Hjalmar Schacht's bilateral treaties yoked Eastern Europe into a German-dominated economic bloc, trade access to this area was hardly a crucial stake in itself. Nevertheless, a Germany that was enrolled in a system of international exchange with the West, as the Weimar Republic had been from 1924 to the Depression,${ }^{59}$ naturally appeared a safer and more decent participant in a liberal international order.

Hence the central conflict defining the international political economy from World War I until about 1950 was not that between American and Soviet alternatives, between capitalism and communism. The Soviet-American antagonism after World War II, in effect, imposed a framework on international politics but did not exhaust the issues. Viewed over the whole half century, the American international economic effort of the era of stabilization centered on overcoming British, Japanese, and especially German alternatives to a pluralist, market-economy liberalism. In the case of Germany, these alternatives were incorporated first in Berlin's vision of Mitteleuropa during Ludendorff's regime of 1917-18 and then in Hitler's expansionist Reich. Defeating these German projects, however, could be only the first stage in erecting a stable alternative. To assure liberal, pluralist stability within each West European country, as well as for the Atlantic region as a whole, required the further step of integrating German economic dynamism into an international system of exchange: perhaps the pre-eminent Western diplomatic task in each postwar reconstruction period.

These respective postwar tasks, however, took more than just German defeat; they also required that the United States assume the burden of funding Germany's international deficits-including reparations - after the two wars. Amer-

\footnotetext{
${ }^{57}$ Richard Gardner, Sterling-Dollar Diplomacy: Anglo-American Cooperation in the Reconstruction of Multilateral Trade (Oxford, 1956); and Benjamin M. Rowland, "Preparing the American Ascendancy: The Transfer of Economic Power from Britain to the United States," in Rowland, ed., Balance of Power or Hegemony: The Interwar Monetary System (New York, 1976), 195-224.

${ }^{58}$ Maier, "The Politics of Productivity," 32-34. Roosevelt's own message calling for the Temporary National Economic Committee investigation on monopoly, April 29, 1938, defined fascism as "ownership of government by an individual, by a group, or by any other controlling private power," an interpretation that linked the attitudes of the "second" New Deal with the concern about Nazi expansionism.

${ }^{59}$ Werner Link, Die amerikanische Stabilisierungspolitik in Deutschland, 1921-1932 (Düsseldorf, 1970); and Gerd Hardach, Weltmarktorientierung und relative Stagnation: Währungspolitik in Deutschland, 1924-1931 (Berlin, 1976), 152-62.
} 
ican reluctance to take on this responsibility until 1924 (and then only indirectly) helped produce the impasses of the five years after Versailles. U.S. willingness to take on the burden after 1947 facilitated the stabilization of the 1950s and 1960s. But American readiness was no automatic decision. As one minor Department of State official wrote before victory in Europe, "It seems certain that Germany has lost the war; but it appears that Dr. Schacht has a very good chance of winning the peace." $" 60$

In light of these developments, the international corollary of the era of domestic stabilization may be viewed as a German-American (or perhaps a trilateral German-American-Japanese) association achieved only after two world wars. Success for this policy was registered not by the rubble of Berlin but by the frustration of such postwar German leaders as Jakob Kaiser of the CDU and Kurt Schumacher of the SPD, both of whom sought unsuccessfully to maintain under democratic auspices a less capitalist and less exclusively Western-oriented German society. ${ }^{61}$ Their very setbacks testified to the triumph of stabilization in West Germany, Western Europe, and the noncommunist countries as a whole. Just as the end of the second war against Germany resolved the international issues left undecided after the close of the first, so the strengthening of Western pluralism after the second war completed the European domestic institutional restructuring begun after the first. Stabilization meant an end to the German problem. It likewise meant winning the adherence of a large enough segment of the working classes to preserve the scope for private economic power and hierarchy that defined liberal capitalism. The achievement was not simply restorative, for the new, very real guarantees of social welfare and social-democratic political participation contributed change even as they purchased continuity.

This suggests that the major sociopolitical assignment of the twentieth century paralleled that of the nineteenth, which saw the incorporation of the middle classes and European bourgeoisie into the political community. The international corollaries of the earlier development were the paralysis and reduction of Metternichian Austria within Europe and the extension of overseas empire. The international corollaries of the new development were the linking to the West of at least part of Germany and the recession of overseas empire: the trajectory from grandeur to welfare. The institutional device for the nineteenth century was parliamentary representation; the institutional foci for the twentieth-century achievement included trade unions, ambitious state economic agencies, and bureaucratized pressure groups-the components of what I have termed elsewhere "corporate pluralism."

Observers have often failed to note the magnitude of the twentieth-century

${ }^{60}$ Joseph Fuqua to Woodrow Willoughby, December 21, 1944, NA-RG 59, International Trade Papers, box 19, F: "Article VII: United Kingdom-General."

${ }^{61}$ Hans Peter Schwartz, Vom Reich zur Bundesrepublik: Deutschland im Widerstreit der aussenpolitischen Konzeptionen in den Jahren der Besatzungsherrschaft, 1945-1949 (Berlin, 1966), 297-344; Werner Conze, Jakob Kaiser: Politiker zwischen Ost und West, 1945-1949 (Stuttgart, 1969); Lewis J. Edinger, Kurt Schumacher: A Study in Personality and Political Behavior (Stanford, 1965); and Ernst Nolte, Deutschland und der Kalte Krieg (Munich, 1974), 208-14, 32223. 
accomplishment because the costs were so distressing. Certainly this essay should not be read as an argument that, because stability resulted, the intervening tyranny, warfare, sacrifice, and resistance lose their historical significance. Still, to ask about significance is to search for meaning, which is just one task of history. To trace the structural principles of collective life must remain an equally valid historical enterprise; and that pursuit compels us to admit that even catastrophic events do not always durably alter the trajectory of institutions any more than the constant slow renewal that procedes in the absence of disaster. Indeed, that continuing change best facilitates the analysis of earlier patterns. If now the institutional solutions of the second postwar era show signs of wear and tear, if the social compromises of the welfare state become precarious as economic growth falters, if the stability of the past generation appears perhaps to have rested on exceptional and transitory advantages, such as the consensus on postwar reconstruction or the ease of securing resources from outside Europe, then we can better begin to understand the recent era not merely as events but as history. 